\title{
Cooperation, Proximity, and Social Innovation: Three Ingredients for Industrial Medium-Sized Towns' Renewal?
}

\author{
Marjolaine Gros-Balthazard ${ }^{1, *(\mathbb{D})}$ and Magali Talandier 2,3 \\ 1 Institute of Geography and Sustainability, Lausanne University, 1967 Bramois, Switzerland \\ 2 Urban Studies Program, Simon Fraser University, Vancouver, BC V6B 5K3, Canada; \\ magali.talandier@univ-grenoble-alpes.fr \\ 3 Urban Planning and Alpine Geography Institute, Grenoble-Alpes University, 38100 Grenoble, France \\ * Correspondence: marjolaine.gros-balthazard@unil.ch
}

Received: 27 February 2020; Accepted: 2 April 2020; Published: 4 April 2020

\begin{abstract}
Over several decades, medium-sized industrial towns have suffered from a combination of economic and political processes: Deindustrialization, metropolization, and withdrawal of public services. After two decades in which they have been somewhat neglected (in favor of metropolises), there have recently been State and European public policies aimed at them. Medium-sized cities are not homogeneous and present several trajectories. Based on quantitative approach in France, we highlight the very diverse socio-economic dynamics of French medium-sized industrial towns. Thus, far from widespread decline or shrinking dynamics, some of these cities are experiencing an economic rebound. This is the case of Romans-sur-Isère, a medium-sized town located in the south-east of France. Focusing our qualitative analyze on this city, we try to understand this type of process. In this medium-sized town, former capital of the shoe industry, local stakeholders, private, and public try to support a productive renewal. The results of our case study highlight the role that cooperation, spatial and organizational proximity, and social innovation could play in the renewal of productive economy in medium-sized industrial towns. Even if the economic situation remains difficult for many medium-sized cities in France as in Europe, we argue that they could have a productive future making and ultimately take advantages of their "medium-sized" attributes.
\end{abstract}

Keywords: proximity; social innovation; industrial town; medium-sized city; territorial development; urban development; deindustrialization

\section{Introduction}

The Yellow Vest movement in France, the Brexit in United Kingdom, and the election of Donald Trump in USA opened the debate on the geographical divide between metropolises and peripheries, rural areas, or small and medium towns. Although the explanation of this movement and these votes is more than spatial [1-4], it has recalled the important issue of territorial inequalities. Indeed, in industrialized countries, the combination of metropolitan positive economic dynamics and the evolution of regional planning policies raise the question of the non-metropolitan areas' future and, among them, that of medium-sized towns. Despite its interest, this question has rarely been addressed, particularly concerning economic and productive future [5-7]. European small and medium-sized industrial towns are clearly overlooked [8]. Over several decades, a large part of these towns has suffered from a combination of economic and political processes: Deindustrialization, metropolization, and withdrawal of public services. In this context, when they are studied, it is often in terms of planning with shrinkage, commercial, or public services decline [9-14]. While they have historically been administrative and industrial centers and despite their importance for national urban systems, it is 
interesting to highlight that dominant narratives do not make them potential productive or innovation centers of the 21st century.

In this context, this paper aims to question a possible productive renewal of medium-sized industrial towns in the case of France. Considering the current economic and politic environment, we hypothesize that their levers and assets are different, of course, from metropolitan areas, but they are still real. Our results show the importance of three drivers of productive renewal: Cooperation, spatial proximity, and social innovation.

To do so, the next section highlights French features about medium-sized industrial towns, especially in terms of urban and regional policies towards them. This French context echoes several recent European politics, which reveal an important turn, and their return at least, in cohesion issues. Section 3 presents our methodology based on two main steps: An overview of socio-economic dynamics of medium-sized industrial towns and the focus on a case study, Romans-sur-Isère. We present our results in the Section 4. We show that there has been, since 1975, a variety of dynamics and paths of French medium-sized industrial towns. Next to declining towns, there are towns that are rebounding. To illustrate this situation and go ahead to answer our question, we develop the trajectory of Romans-sur-Isère, located in the southeast of the country. Formerly the international capital of luxury footwear, after a period of socio-economic crisis, this medium-sized town is being revitalized under the action of local stakeholders. They have been able to mobilize the local available resources and combine them with national policies to promote a productive renewal. Then, the discussion establishes the central role of stakeholder's cooperation, facilitated by proximity, and social innovation as productive renewal's driver for Romans-sur-Isère, joining European recent studies. We conclude by a reflection upon medium-sized as a new asset and give some tools for public policies outside France based on our results.

\section{Specific Features about French Medium-Sized Industrial Towns}

In recent decades, the research in urban studies and regional science has well analyzed the concentration of people and activities and its economic and spatial consequences [15]. While the productive economy seems to be concentrated in metropolises, the productive destiny of medium-sized towns is of little interest to either researchers or policy makersand is often denounced [16]. Considering this global context, in this section, we present the economic situation of French medium-sized industrial towns and the public policies towards them.

Before beginning, we should note that in France, the notion of a medium-sized city does not correspond to institutional division and remains poorly defined. However, it is generally considered as a city with 20,000 to 100,000 inhabitants.

\subsection{To be a Medium-Sized Industrial Town in the "Metropolized" World}

Since the 1970s, the process of deindustrialization has particularly weakened medium-sized industrial towns because of relocation of manufacturing, factory closures, and their consequences in terms of job losses. They have suffered from their dependence on manufacturing activities inherited from a long past, which are concentrated around a reduced number of sectors of activity and production units, and linked to their subordinate position in the spatial division of labor with few cognitive and design functions (while it is these functions that are developing). The decline in industrial activities, which were once the pride and strength of certain towns, has brought about far-reaching upheavals, with a cumulative, downward effect. The divergence of local economies in industrialized countries has been the subject of several studies, such as those focusing on Britain [17] or within the Rust Belt [18,19], but globally, other cities with an industrial past have recorded poorer economic performances than others according to the following quote [20] (p. 9): "historically industrial (especially manufacturing) small and medium-sized towns have been facing more problems of unemployment over the last ten years due to global competition. Moreover, towns which continue to rely on industrial employment 
face a problematic future as a higher proportion of employment in industrial activities is associated with poorer job growth".

While medium-sized industrial towns are not the only areas to undergo these changes [13], as large cities also suffer [21], in France, there are also converging economic and political processes common to all small and medium-sized cities, i.e., decentralization, metropolization, increased mobility, and the withdrawal of a number of public services and facilities [14,22]. Some of them are also marked demographically by a decline of their population [10], like in other countries [23-25]. This well-known phenomenon of shrinking cities is an important and growing subject, particularly in terms of planning $[24,26,27]$. Not all of them have an industrial history, so debates on shrinkage cities are just a little part of our subject. Nevertheless, we must highlight that policies towards them are often growth-oriented especially through strategies based on population attractiveness and residential development [24,27]. In line with our problem, in France, like elsewhere, alternative strategies, e.g., right-sizing ones [27-29] or strategies based on endogenous resources are fewer in number.

For some, the consequence of this downgrading is the electoral geography, especially populist votes, which has, as elsewhere, espoused this geography of places that do not seem to matter [21]. In this context, which is not very favorable to medium-sized industrial towns, many empirical studies have highlighted the rising concentration of knowledge 'skills' in the world's major cities in the 1980-1990s [30-32].

As a result, the research focuses on large cities, which are considered as the only territories of growth and innovation [7,33-35] and are increasingly dependent on agglomeration economies [35-38]. Over one-third of the population ( 25 million inhabitants) and a half of the gross national product are now concentrated in French metropolitan areas. Because they are seen in the international and national literature (and public reports) as drivers for the other towns and regions owing to redistribution mechanisms, several national policies promoted them for two decades. The fact that metropolises were less impacted by the 2008 crisis than other European territories reinforced this conviction [39]. At the European scale, they were seen as the main drivers of countries' economic recovery and have received special attention. Thus, the crisis reopened the debate on the trade-off between cohesion or competitiveness, between "balanced development" and "growth-oriented development" [40,41]. Following the second way, in France, two laws (2010 and 2014) created a special status conferring on them a large number of competences in the fields of spatial planning, economics and social and cultural development. The hypothesis is that their growth would benefit the other territories through mechanisms of income redistribution to the peripheries by the trickle-down effect [42]. However, the debates on the effects of these policies are still important and reopen European controversies concerning these trade-offs. For some, the support for metropolises not only hierarchizes and fragments space, but also shows the loss of influence of medium-sized cities [43]. The promotion of a more balanced development is based on the reduction of existing disparities, avoiding territorial imbalance, and making territorial diversity an asset [44,45].

Despite this growing focus, a combination of plans, disposals, and laws have helped medium-sized industrial towns since the 1970s.

\subsection{Are Medium-sized Industrial TownsTruly Outside the French Urban and Regional Policies' Targets?}

Medium-sized industrial towns are at the crossroads of the evolution of the policies of medium-sized cities and industrial policies. In recent years, they have appeared on the fringes of the debates in the face of metropolises that monopolize the attention, programs, and funding [46]. While planning policies specifically dedicated to medium-sized cities no longer truly support their productive future, recently implemented industrial policies are expanding their interventions outside of metropolitan areas.

From the 1960s to the 2000s, medium-sized towns, boosted by the rural exodus, were a category of public action in France [13] with an objective of territorial cohesion. Some of them first benefited from industrial decentralization policies after the Second World War. Then, in 1973, the State launched 
the "policy for medium-sized towns" (targeting 70 municipalities with 20,000 to 100,000 inhabitants), which aimed to improve housing conditions, facilities, and urban services by financing urban planning operations [9]. The priority was then to ensure a certain equality between French people, regardless of their place of residence. In the 1990s, this objective was pursued with more sectoral (urban and university) actions. However, from the 2000s, in a context of metropolization, medium-sized cities were completely excluded from spatial planning policies, or even subjected to the State's territorial disengagement policies (closure of public services) [14]. Growth-oriented regional policies were dominant.

In 2017, after acknowledging this 'omission', the Minister for Territorial Cohesion launched a plan, called the 'city core action'. The aim of this plan was to strengthen the attractiveness of medium-sized towns by responding to the following three challenges: Boosting the housing supply to invite inhabitants to return to town centers; defending town center commerce by working, in particular, on simplifying standards; and maintaining certain decentralized State services in medium-sized towns. Both public action and experts still believe that medium-sized towns can have a residential future and play an intermediary role in helping to reduce the divide between rural and large cities [13,47-50]. In many studies, these cities appear as places of access to shops and intermediate services for the inhabitants of lower density areas. On the other hand, their capacity to once again become major production and innovation centers seems less obvious [6,51]. However, it would be premature to conclude that medium-sized cities have no support for their industrial development, as there is an evolution of forms and means as well.

In the 1980s, spatial planning and conversion measures at the State level showed their limits when deindustrialization took on a structural character. This awareness occurred at a time when the institutional context was changing: The first decentralization laws granted greater autonomy to local authorities in terms of economic and social life. Spatial redevelopment measures, characterized by a better consideration of the specificities of local contexts and the involvement of a greater number of local stakeholders alongside the State, were developing. In line with what was mentioned earlier, they open the way to longer-term actions and are no longer always aimed at redevelopment by industry (or by the productive economy as a whole). In the 2000s, these measures took shape through the following two main tools: The revitalization agreement (2002) and the site contract (2003). Alongside these reconversion policies, which were rather defensive or even palliative, other industrial policies focused on supporting dynamics based on innovation and the search for competitiveness developed during the 1990s and 2000s (e.g., the policy of competitiveness clusters in the cluster spirit). Geographically, this focus translates into a shift of attention towards the economic territories deemed to be the most competitive, i.e., the metropolises.

However, since the beginning of 2010, the industrial policy has gradually become a priority political issue (consultation of the Etats Généraux of industry, setting up of a Ministry for Productive Recovery, etc.) with a spatial focus that is widening outside the metropolises.

In 2019, two programs launched by the State specifically address the challenges of productive redevelopment in medium-sized towns. Both concern our case study, Romans-sur-Isère.

On the one hand, the government has identified 124 territories, that are outside metropolitan areas, and have strong industrial issues as "industrial territories". No new funding is planned, the aim being to concentrate the funding from existing envelopes to carry out projects (jobs, innovation, and training). Management is decentralized. The approach is steered by an elected/industrial binomial, and the projects are designed in consultation with local players. It is seen as "a very good model for the entire policy concerning SMITs [small and medium-sized industrial towns] in Europe" [52] but we do not know its results yet. In addition, under the Investment Program for the Future, a call for projects entitled "Innovation territories" has been issued. The projects have various themes (agricultural and food transition, energy and ecological transition, health, mobility, digital, skills), and aim to create new, reproducible, and exemplary models of local development. These new models should encourage "the emergence of ecosystems conducive to sustainable economic development and the improvement of 
people's living conditions, while allowing local economic players to shine" [53] (p.6). Stakeholders from the same territory were called upon to propose a collective strategy to innovate in this field. Among the 24 winners announced in November 2019 are six metropolises rub, nine medium-sized towns (including Romans-sur-Isère) and eight other rural territories.

It is now quite certain that policies in favor of growth areas and those of redistribution are not enough, and policies adapted to the specificities of each area are necessary [21]. In France, while the amounts may not be sufficient, we cannot say that the socio-economic issues of medium-sized industrial towns are absent from public and regional policies. After a period of neglect in the 1980s-1990s, when the focus was almost exclusively on metropolises, policies able to support their productive rebound are reappearing. However, the modalities are very different from the historical policies of regional planning. Whether or not they are directly competing (call for proposals), these cities must now know how to best mobilize their resources (especially human and cognitive resources) to benefit from them.

Before we detail our results, we first present our methodology.

\section{Methods}

This section presents the mixed methods that we used. Mixed-methods research argues that better findings can be expected by combining qualitative and quantitative methods rather than prioritizing one research paradigm over another [54-58]. This paradigm based on their complementarity seems to be more reflective of the complex and systemic building process of social science. Rather than combine them, we used them successively to benefit from their various advantages. Indeed, our method consisted of two main steps, the first one quantitative and the second one mainly qualitative. We explain and detail below.

Medium-sized industrial towns are often described as decreasing or shrinking in France as well as in Europe. So, firstly, we aimed to capture the diversity of their socio-economic trajectories. Thanks to several employment data collected since 1975, we constructed a typology to make an overview of this diversity.

To localize French medium-sized industrial towns, we based our calculations on the spaces that France's National Institute of Statistics and Economic Studies (INSEE) classifies as living areas. This division is functional and not institutional. It encompasses several municipalities and "represents the smallest territory on which inhabitants have access to the most commonly available facilities and services" (INSEE). We think that a scale based on city perimeter is not really adapted to estimate economic dynamics over time, especially because of the augmentation of pendular mobilities (let us estimate that there are 35,000 municipalities in Franc; a lot of them are very small in terms of space and inhabitants). There are 1644 living areas in mainland France, with populations varying from less than 2000 to over 10 million for the Paris living area. Then, we measured the industrial character of these areas by the industry's share in the overall workforce. To define the limits of the industrial sector, we adopted the classic analysis used by Clark [59], distinguishing primary, secondary, and tertiary sectors. The secondary sector corresponds to the industry. However, unlike Clark, we have included mining activities. Admittedly, changes are underway that have close links between industry and services, but we believe that this method offers a good approximation of what can be described as a "traditional industry".

Our definition of the industrial tradition of these areas is based on the share of industrial jobs in relation to total jobs in 1975 (based on census from INSEE). It shows a country that was still deeply industrial, with over a quarter $(27.5 \%)$ of all jobs in the industry. Since no natural threshold appears, we retained areas belonging to the upper quartile of industrial jobs (over 34\%), which was 411 areas. Then, we removed the six metropolitan living areas that are structured around a city with more than 100,000 jobs and living areas with less than 20,000 inhabitants (considered as small). Thus, we obtained a database of 190 living areas that are considered as French medium-sized industrial towns for our analysis. Among situations of shrinkage and decreasing, we found that some French medium-sized industrial towns were engaged in an economic renewal. 
Secondly, to understand how this renewal is possible and what are its roots, we decided to focus on a specific case, Romans-sur-Isère, for which we deployed a qualitative approach. Among the other towns characterized by this kind of trajectory, this case is particularly relevant for several reasons. Its trajectory is typical of the process of deindustrialization of French and European medium-sized industrial towns. It was specialized in a manufacturing sector, footwear, and in an original way, strategies for renewal partially build on that past towards a productive future. It is also a territory, which has become pilot and experimental for some interesting policies and initiatives that could support a productive rebound. Studying this mechanism of productive renewal could give us some clues for European medium-sized industrial towns.

Our hypotheses are that coordination between local stakeholders and endogenous resources could explain this renewal. To validate or confirm it, we met stakeholders, studied the story of this town, understood the local public policy, the impact of national program and public funds, and observed the coordination between public and private sectors.

To do so, we employed the use of descriptive statistical data (all from INSEE except when otherwise mentioned) and, more importantly, two main qualitative materials collected over a period of 4 years. First, 11 interviews were conducted with local actors in 2016 and 2017, particularly with institutional and business stakeholders, to understand the local economic history and the current strategies to promote a productive future (Table 1). The interviews lasted one to two hours and were recorded. Each interview was transcribed for later analysis.

Table 1. Summary of interviews.

\begin{tabular}{|c|c|c|}
\hline Date & Fonction & Structure \\
\hline 02/11/2016 & $\begin{array}{l}\text { Responsible for higher education, } \\
\text { innovation and tourism }\end{array}$ & Urban community Valence Romans Sud Rhône-Alpes \\
\hline 03/11/2016 & Mayor & Town of Romans-sur-Isère \\
\hline 07/11/2016 & $\begin{array}{l}\text { Territorial development project } \\
\text { manager }\end{array}$ & Town of Romans-sur-Isère \\
\hline 10/11/2016 & Project manager & House of employment, enterprise and training \\
\hline 10/11/2016 & Director & House of employment, enterprise and training \\
\hline 10/11/2016 & $\begin{array}{c}\text { Head of the economic change } \\
\text { Division }\end{array}$ & $\begin{array}{l}\text { Regional Directorate for Enterprise, Competition, } \\
\text { Consumer Affairs, Labour and Employment }\end{array}$ \\
\hline $15 / 02 / 2017$ & Lecturer & Grenoble-Alpes University \\
\hline $13 / 03 / 2017$ & Manager & 1083 (a company) \\
\hline $13 / 03 / 2017$ & Business Manager Industry & $\begin{array}{l}\text { National Agency for Adult Vocational } \\
\text { Training-Auvergne-Rhône-Alpes Region section }\end{array}$ \\
\hline 22/03/2017 & $\begin{array}{l}\text { Territorial development project } \\
\text { manager }\end{array}$ & Auvergne-Rhône-Alpes Region \\
\hline 27/03/2017 & Chairman and CEO & Veyret Techniques Découpe (a company) \\
\hline
\end{tabular}

Second, from 2018 to 2019, we were able to track and accompany the actors of the territory in the setting up of the project ("Capital of the territory start-ups"), which was in response to a national call for projects from the French government (Plan for Investment Future). This form of participatory observation is based on our presence throughout the application process. We participated in a creative evening where 1500 persons were present, co-animated one workshop with local entrepreneurs, we were mobilized for several meetings of the governance team (10 meetings), and we organized an observation field trip to meet different economic stakeholders.

\section{Results}

This section presents all of our results, from the diversity of medium-sized industrial towns trajectories, which relativizes their socio-economic difficulties, to the redevelopment trajectory of Romans, through which we see cooperation and social innovation as two levers that can foster the productive future of medium-sized industrial towns. 
We know that deindustrialization has weakened French medium-sized industrial towns, but the observation of the quantitative variables shows diverse trajectories, which we explained in the first sub-section. One of the trajectories is qualified as "mutation", which describes a diversification of the local economy and Romans-sur-Isère is a typical case. Our qualitative approach allowed us to better understand and characterize these deep changes.

\subsection{Disparate Dynamics of French Medium-Sized Industrial Towns}

Figure 1 shows the location of French medium-sized industrial towns, with some regional logics and the historical divide between the industrialized East and the under-industrialized West. Indeed, by the middle of the 20th century, three regions-Hauts de France (south of Lille and inland from Calais), former Rhône-Alpes, and Grand Est (stretching from the Ardennes to Mulhouse city)_formed France's industrial heartland, enjoying flourishing growth and industrial development until the 1970s owing to traditional industries, such as steel, metalworking, and textiles. In 1975, these French medium-sized industrial towns accounted for $15.7 \%$ of the national population, $15.3 \%$ of total employment, and $25.3 \%$ of industrial employment. In 2016, they accounted for $16.2 \%$ of the national population, $13.2 \%$ of total employment, and $21.8 \%$ of industrial employment. These figures show that they are growing less rapidly than the rest of the country (or decreasing more quickly), both in demographic and employment terms. The deindustrialization has been hard with a loss of $57.8 \%$ of industrial jobs $(-50 \%$ at national level), 840,000 jobs, which represents $28.6 \%$ of the national decline. Despite this decline, total employment in these living areas still increased by $6.5 \%$ over the period, which is well below the national average $(23.6 \%)$.
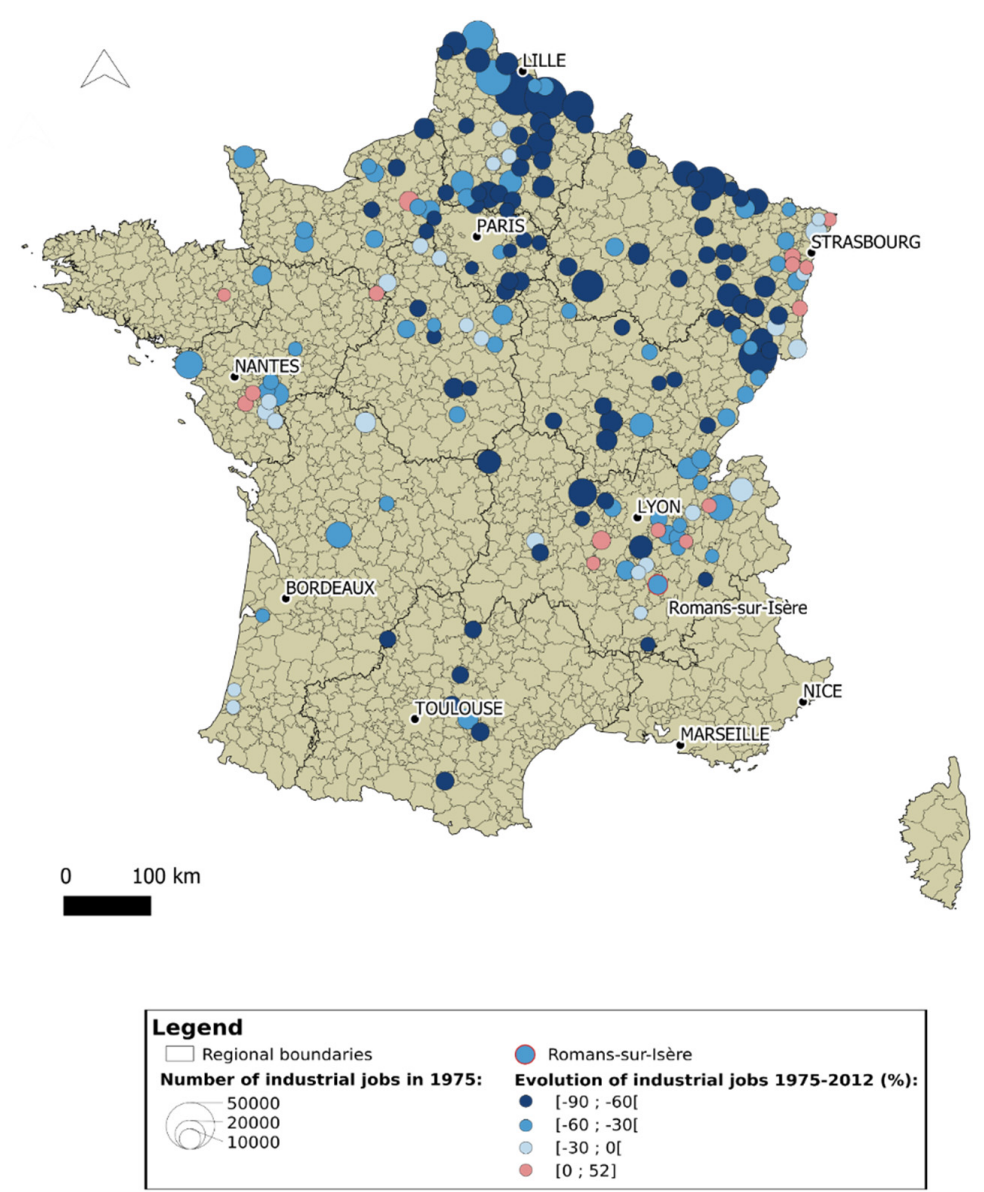

Data : IGN, 2014, Population Census (INSEE), 1975 \& 2012

Figure 1. Location of French medium-sized industrial towns (source: Authors). 
It is necessary to go beyond these figures and discussions homogenizing the dynamics of these territories to highlight their great disparity. Data show that the population has declined in a quarter of these areas over the period and Figure 1 already highlights that the industrial was not geographically uniform between 1975 and 2016. It was stronger than at the national level in the medium-sized industrial towns highlighted in dark blue, which are located mainly in the northeast of the country. In red medium-sized industrial towns highlighted in red, industrial employment has even increased over the period.

To study the differentiated dynamics of industrial living areas since 1975, here we propose approaching the variety of local processes by identifying and qualifying the economic trajectories of these living areas. The construction of theses trajectories requires the use of existing data at the municipal level, which can be re-aggregated afterwards and are available over a relatively long period (since 1975). Given the temporal amplitude, we used data from the population census, relating to employment at the workplace. We compared the evolution of total employment and industrial employment over 1975 to 2016. We, thus, determine three trajectory forms, as follows, two of which have variants (Figure 2):

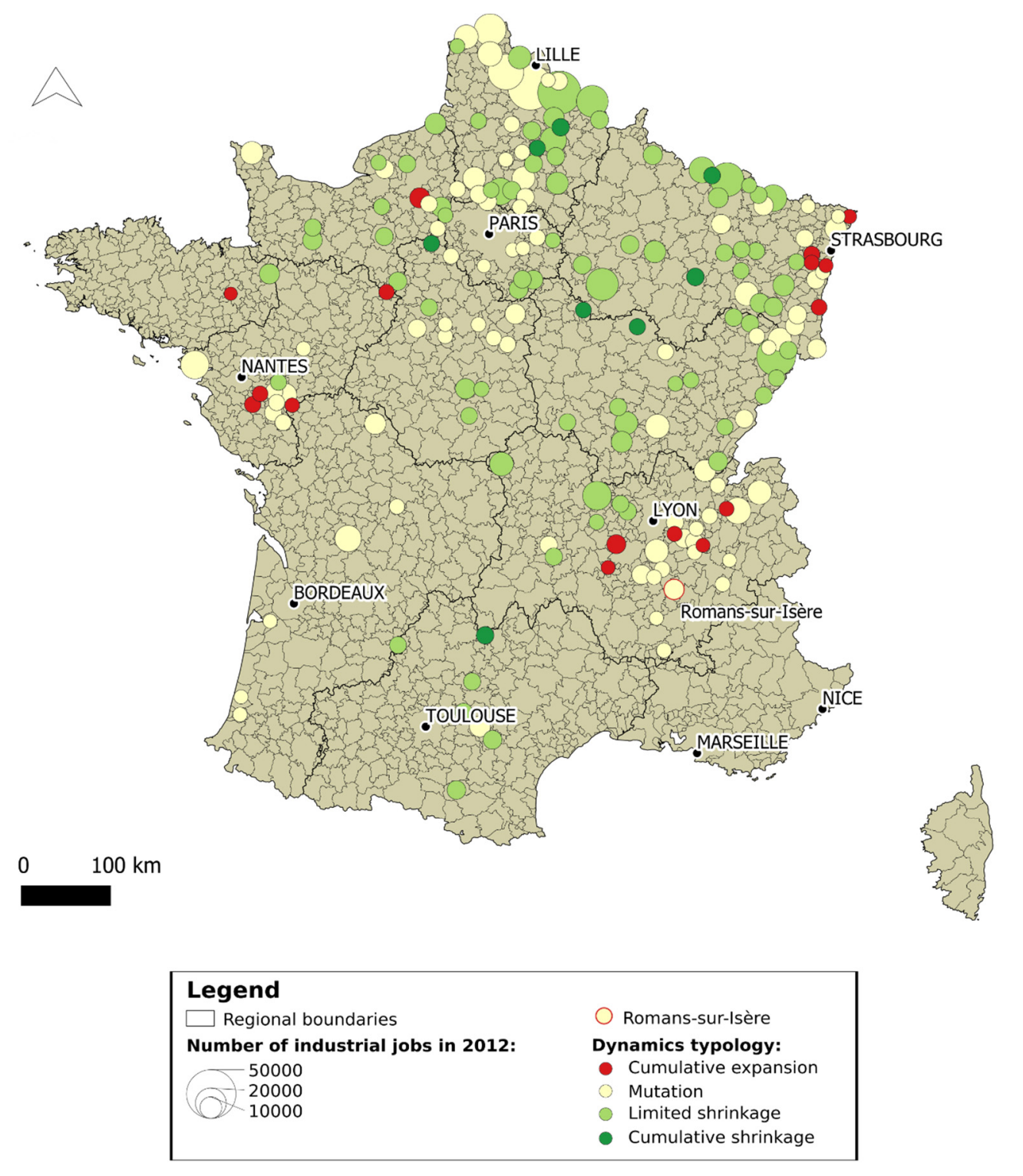

Data: IGN, 2014, Population Census (INSEE), 1975 \& 2012)

Figure 2. Typology of French medium-sized industrial towns' dynamics (source: Authors). 
Shrinkage, when total employment and industrial employment have declined; we call it limited when total employment has declined less than industrial employment, and cumulative otherwise.

Expansion, when total employment and industrial employment have increased; we qualify it as limited when total employment has increased less than industrial employment, and cumulative otherwise.

Mutation, when total employment has increased despite a decline in industrial employment.

Half of the living areas hosting French medium-sized industrial towns are shrinking, but for almost all of them, the decline in total employment has been less than the decline in industrial employment. The growth of other jobs has alleviated the socio-economic difficulties. Only $4 \%$ of the geographically widely dispersed living areas are in cumulative shrinkage: They are living areas that have been the most weakened socio-economically by the changes described. Eight percent of the living areas are in cumulative expansion, i.e., industrial employment and total employment have increased over the period. Finally, $46 \%$ of the living areas are undergoing change, as other economic drivers have taken over in the face of deindustrialization. These economic drivers are both residential jobs (i.e., services for the population) and productive non-manufacturing jobs (i.e., services for businesses).

Various factors explain these discrepancies, including sectoral effects (specialization of these medium-sized industrial towns in traditional industrial sectors) and spatial effects, which are not an unknown in economic geography or regional science [60]. Figure 2 attests to the "region" effect [61] with situation of cumulative expansion mainly located in three regions and situation of shrinkage especially in the northeast of the country. While we cannot ignore the influence of these structural mechanisms, they cannot explain the wide variety of territorial trajectories. Multiple local factors also have an influence, such as as city-specific factors (land and property prices, infrastructure, governance, company size, dependence or not on a group, nationality and territorial anchoring of the group to which the company belongs, etc.) $[17,20,62-65]$.

In the same context of strong destabilizing economic changes, we observe a great diversity of dynamics of French medium-sized industrial towns, joining results of the project Bright Future for Black Towns for other European countries [8]. We can see two main paths that stand out, i.e., shrinkage and mutation. Thus, for most French medium-sized industrial towns, there is either no renewal (or not entire yet) or a non-productive renewal. Does that mean they have no productive future?

Considering these results, we look at a case study that can bring us elements to answer this question. We have particularly considered the mutation trajectories deemed most relevant for this purpose. Among different towns, we choose Romans-sur-Isère as we have already explained in the previous methodological section.

\subsection{Case Study: Romans-sur-Isère and Its Socio-Economic Dynamics}

The Romans-sur-Isère living area is located near Valence, in the Rhône-Alpes-Auvergne Region (Figures 3 and 4). It has a total population of 75,000. Between 1975 and 2016, the population grew by nearly $25 \%$, or nearly 20,000 additional inhabitants under the combined influence of natural and migratory growth. More than $40 \%(33,000)$ of the inhabitants live in the city center. It occupies a strategic geographical position in the heart of the Rhone Valley, close to the motorway and a TGV station. Far from the metropolitan areas of influence (Grenoble, Lyon), its development trajectory is relatively independent from them, which also means that when facing deindustrialization, it has not benefited from their economic dynamism. 


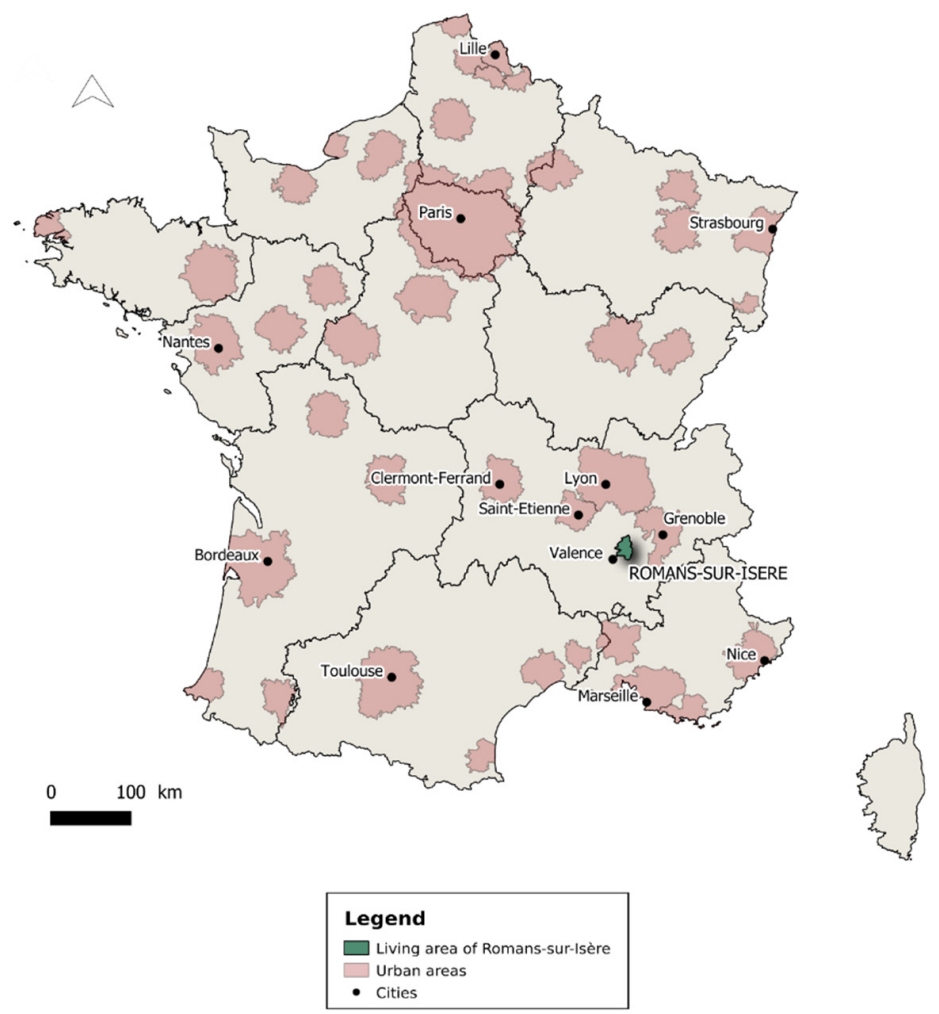

Figure 3. Location of Romans-sur-Isère (source: Authors).
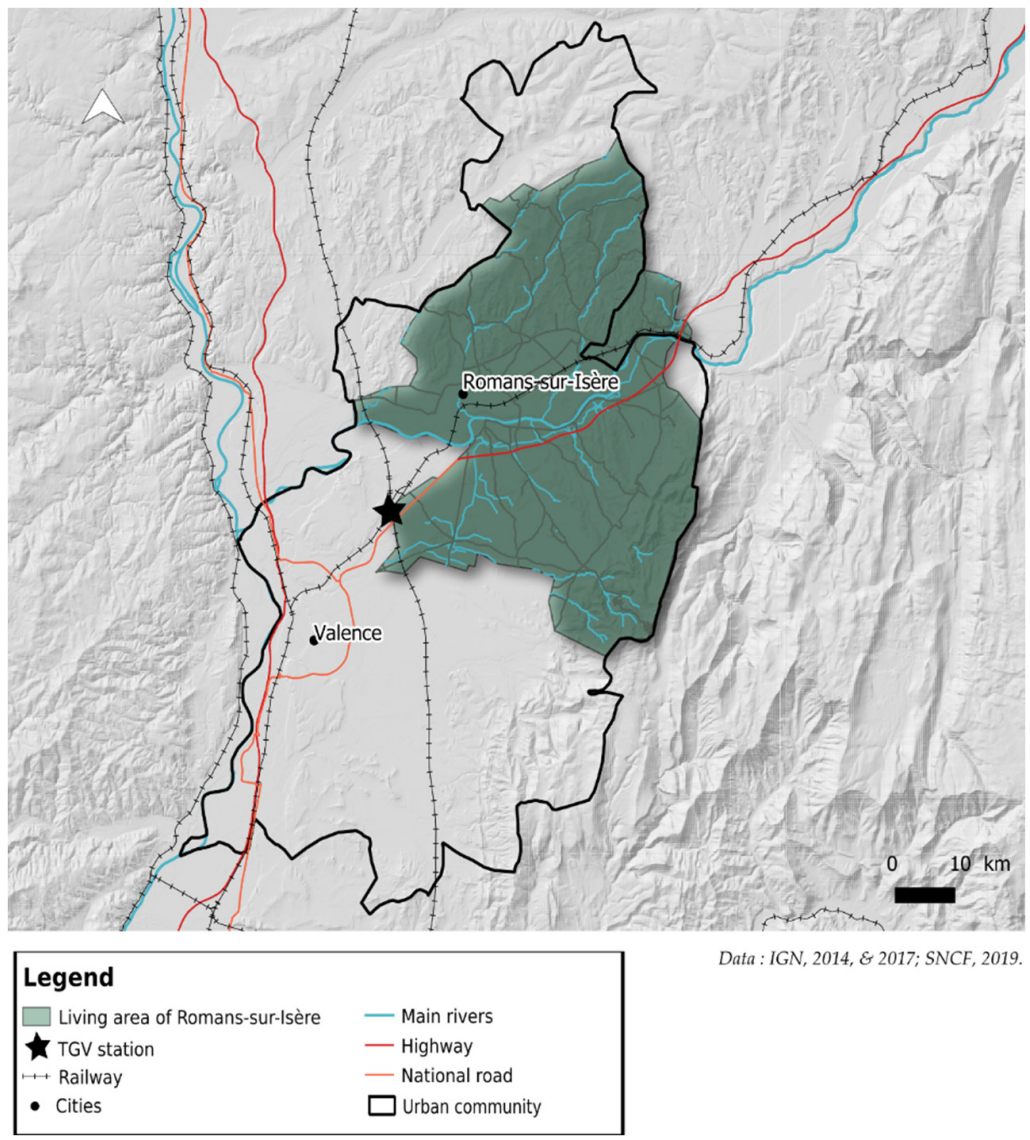

Data : IGN, 2014, \& 2017; SNCF, 2019.

Figure 4. Location detailed of Romans-sur-Isère (source: Authors). 
Romans-sur-Isère is a perfect illustration of the crises that all medium-sized industrial towns face, including all the processes that we have described, and the support from public policies. It has faced the gradual decline of its mono-industry, i.e., the shoe industry.

The shoe industry emerged as a proto-industry in Romans-sur-Isère in the middle of the 19th century owing to a combination of several factors, as follows: Immediate proximity to the tanneries, workers available following sectoral crises, the arrival of the railways, technical innovations, etc. In spite of the economic crises experienced, from the inter-war period onwards, Romans-sur-Isère gradually asserted itself as the international capital of luxury footwear. After the Second World War, the shoe business reached its peak. The number of workshops increased and the local industry produced $12 \%$ of the value of shoes produced in France [66]. The Charles Jourdan company became world renowned for women's footwear. Until the 1970s, the movement of concentration between companies and the abandonment of low-quality production did not prevent an increase in the number of jobs in the footwear industry or a rise in the number of indirect stakeholders in the sector. For some, this local industry was akin to a localized production system $[67,68]$.

In 1983, more than half of the inhabitants of Romans-sur-Isère were still living off the shoe industry. However, the first economic difficulties began in the 1960s, with the closure of medium-sized businesses. The decline came in successive waves until the closures of Charles Jourdan and Kélian in the 2000s, two major employers in the area. There were several reasons for this decline, as follows: International competition, retirement of managers, and takeovers by foreign investors. The decline of employment in the footwear manufacturing sector was severe, declining from 1400 in 1993 (or 9.5\% of private salaried employment in the living area) to less than 200 in 2007 (or 1\% of private salaried employment) (data from Unedic (unemployment insurance administration)). Another sign of this significant decline occured in 1999, when was when the local training courses related to footwear (cutting, assembly, pattern making, design office, stitching) were closed.

Between the 1980s and the mid-2000s, when two of the three big shoe factories closed, the economic crisis led to a sharp decline in industrial jobs and a sharp increase in unemployment. The industry sectoral crisis became a social and territorial crisis. In the face of the economic and social difficulties encountered, the Romans-sur-Isère living area gradually moved towards economic diversification, both industrial and commercial.

Private dynamics contributes first to industrial diversification. Since the 1990s, the boom in luxury leather goods, due to the presence of sub-contractor workshops or those belonging directly to luxury brands (Vuitton, Hermès), located north of Romans, contributed both to the reemployment of a large number of former shoe workers and to the maintenance of the leather industry in the region (suppliers of raw materials, laces, machine tools, etc.). At the same time, companies previously working exclusively for the footwear and leather sector are reorienting their activities and diversifying their outlets. The food-processing industry is continuing to develop in parallel by promoting local specialties (ravioles, pognes). Then, at the end of the 1990s, the economic diversification was supported mainly by exogenous drivers and unrelated to the specificities and resources of the territory (planning of the Rovaltain economic area close to the high-speed train station; opening of Marques Avenues, a leading shopping center with 90 shops that attracts approximately 1.5 million visitors a year).

Following our results of "mutation", the data show an economy quite diversified today, with a preponderant weight of trade (14.5\%). Agriculture has retained an important place in the local economy and coexists perfectly with the other sectors. Owing to the automotive, nuclear fuels, energy, aeronautics, and food-processing industries, the industry base is developing once again. Nevertheless, the productive sphere remains fragile and jobs are struggling to develop. The residential sphere, which represented more than $60 \%$ of the local jobs in 2015 , has not taken up the slack (in regard to other regions). Thus, the apparent diversification should not obscure the socio-economic difficulties that remain. 
In 2016, there were 5000 industrial jobs, i.e., 17.6\% of total employment, compared with 8200 in 1975 (36.5\%). Brownfields lands and vacant shops are still a visible sign of this industrial and economical decline (Figure 5).

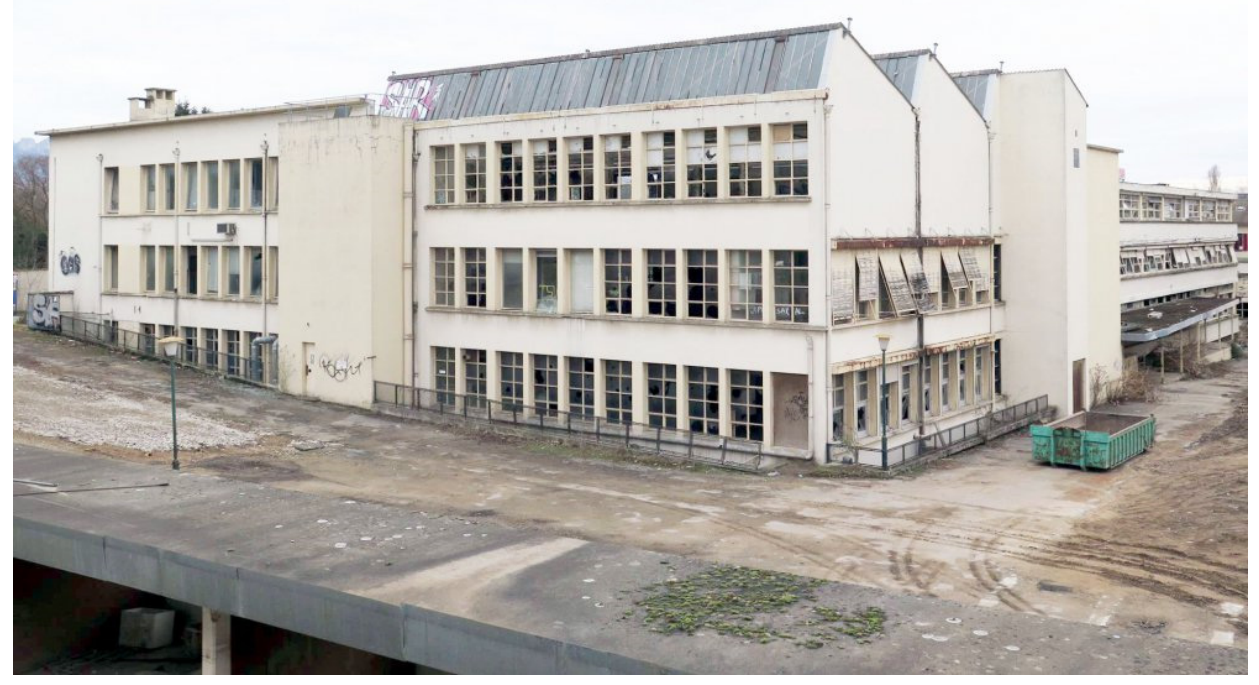

Figure 5. Wasteland of the Jourdan company in Romans-sur-Isère city center (source: 1083).

The level of unemployment is still higher in the town than at the living area (which is near the national level) with $16 \%$ of the active population and almost $25 \%$ of the workers population unemployed (versus $11.5 \%$ and $18.5 \%$, respectively). The poverty rate also remains very high, particularly in the city center, creating spatial and economic segregation, with more than $21 \%$ of the population of Romans-sur-Isère living in the city's priority district. These factors create social and economic fragility and inertia, which can make it difficult for the territory to bounce back and alter its image and attractiveness.

In this difficult context, we can however observe a succession of territorial redevelopment measures conducted by local stakeholders towards a productive renewal.

\subsection{Romans-sur-Isère: A Succession of Territorial Redevelopment Measures}

In the shoe industry, Clergerie is the only big company that has survived the local crisis. Bought out in 2011 by a Chinese investment fund, First Heritage Brands, it still employs approximately 100 people and combines subcontracting abroad and local manufacturing in Romans-sur-Isère. There are also smaller companies specializing in niche, timeless markets, as well as small generalist companies, with seasonal collections and a very targeted clientele, that have maintained their production in Romans-sur-Isère or nearby for decades.

Alongside that, in the context of deindustrialization that we have just described, since the middle of the 2000s, several public policies have been mobilized from national and local scales towards a productive renewal: On the top-down side, site contract, city core action, and industry territories label, and on the bottom-up side, Territorial Pole of Economic Cooperation and Innovation territories. We leave out city core action and industry territories label, very recent policies (2019), on which we have no results. We synthesize the three mains policies that we develop in the following paragraphs in Table 2. 
Table 2. Characteristics of three important policies for Romans-sur-Isère (source: Authors).

\begin{tabular}{|c|c|c|c|c|c|c|}
\hline Date & $\begin{array}{l}\text { National } \\
\text { Policy }\end{array}$ & Modality & $\begin{array}{l}\text { Objective of the } \\
\text { National Policy }\end{array}$ & Subvention & Local Objectives & Project Leader \\
\hline 2006 & $\begin{array}{c}\text { Site } \\
\text { contract }\end{array}$ & $\begin{array}{c}\text { State } \\
\text { decision }\end{array}$ & $\begin{array}{c}\text { Reconversion policy } \\
\text { by supporting a } \\
\text { wide variety of } \\
\text { actions }\end{array}$ & $\begin{array}{l}27 \text { million } \\
\text { euros }\end{array}$ & $\begin{array}{l}\text { Taking action } \\
\text { around three } \\
\text { components } \\
\text { (exogenous } \\
\text { development, } \\
\text { employment and } \\
\text { industry-research) }\end{array}$ & $\begin{array}{c}\text { Local } \\
\text { representatives } \\
\text { of the State in } \\
\text { consultation } \\
\text { with various } \\
\text { local } \\
\text { stakeholders }\end{array}$ \\
\hline 2014 & TPEC & $\begin{array}{l}\text { Call for } \\
\text { project }\end{array}$ & $\begin{array}{l}\text { Bringing together } \\
\text { social economy } \\
\text { enterprises around } \\
\text { economic, social } \\
\text { and territorial } \\
\text { development } \\
\text { projects. }\end{array}$ & $\begin{array}{l}150,000 \\
\text { euros }\end{array}$ & $\begin{array}{l}\text { Bringing together } \\
\text { different local } \\
\text { organizations to } \\
\text { promote local } \\
\text { industrial activity } \\
\text { (organization } \\
\text { existing locally } \\
\text { since 2007) }\end{array}$ & $\begin{array}{l}\text { Archer social } \\
\text { company in } \\
\text { collaboration } \\
\text { with the regional } \\
\text { association of } \\
\text { social economy } \\
\text { (CRESS) }\end{array}$ \\
\hline 2019 & $\begin{array}{l}\text { Innovation } \\
\text { territories }\end{array}$ & $\begin{array}{l}\text { Call for } \\
\text { project }\end{array}$ & $\begin{array}{l}\text { Developing some } \\
\text { local demonstrators } \\
\text { of innovation, } \\
\text { which promote a } \\
\text { more sustainable } \\
\text { territorial } \\
\text { development }\end{array}$ & $\begin{array}{l}7,5 \text { million } \\
\text { euros }\end{array}$ & $\begin{array}{l}\text { “Capital of } \\
\text { Territory Start-Up" } \\
\text { project aiming to } \\
\text { create a } \\
\text { Productive city }\end{array}$ & $\begin{array}{c}\text { Urban } \\
\text { community } \\
\text { Valence-Romans, } \\
\text { Archer social } \\
\text { company and } \\
\text { Grenoble-Alpes } \\
\text { University }\end{array}$ \\
\hline
\end{tabular}

In 2006, with the shock induced by the significant closures of the Charles Jourdan and Kélian companies, the French government announced the implementation of a site contract. This resulted in a significant financial windfall (mainly from the State) supporting a wide variety of actions with the same revitalization objective: For example, the extension and development of business parks, the creation of a platform for the reclassification of employee, or the encouragement of companies in the leather/shoe sector to work in synergy.

Following this site contract (and according to some interviewees, thanks to it), the first Territorial Pole of Economic Cooperation (TPEC) created in France started in Romans-sur-Isère in 2007, i.e., seven years before the official French law. Called Pole Sud Archer, it is labeled in 2014 among others after winning a call for projects launched by the State. This is one of the essential elements of the revival of shoe production. It brings together more than 25 organizations (social companies and representatives of networks, companies and business groups, local authorities, and local partners in employment, training, and employee services), most of which are on the same site. The cluster's main action is to promote local industrial activity.

Then, in 2008, by buying a production line from the company Jourdan, Archer, the local mainstay of the social economy, through its activities of integration through economic activity, created Made in Romans, which subcontracts the production of major brands and produces in its own name. Made in Romans currently employs approximately 10 people, but since its creations has attracted several entrepreneurs who created, for example, Insoft in 2012 (light booties then sneakers); 1083 in 2013 (jeans and then sneakers); Milémil in 2014 (football shoes); and Soulier Français in 2015 (production for another bigger company and offer a multi-service platform for independent designers) in Romans-sur-Isère or nearby.

In 2016, this ecosystem initiated the experimentation called "Territory Start Up". It aims to support the implementation of entrepreneurial projects that provide solutions in various sectors: energy, transport, agriculture, circular economy, etc.This initiative is based on creative evenings, where for the first time in 2016, several hundred people, led by a moderator, submitted approximately 100 ideas, and ultimately approximately 15 regional start-up projects around the major issues of the time (short food distribution channels, development of tomorrow's energies, artistic and cultural creation, 
collaborative economy, etc.). In 2018, on the third evening, 1500 participants gathered to come up with innovative ideas for services or businesses that meet the local needs identified. The first working groups have been launched. More than 10 other towns in France tried to develop the same dynamic and organized creative evenings to promote a new local entrepreneurial, sometimes in partnership with European entrepreneurs, like in Alsace. Although the initiative is currently mainly present in France, it is of interest to international networks, such as the Fab-city, or the European Union. Some of these experimental areas have been able to benefit from "European Solidarity Fund".

In 2019, as a result of these initial experiences, the urban community Valence-Romans, the Archer social company, and Grenoble-Alpes University have applied for the "Innovation territories" call, already mentioned, with their "Capital of Territory Start-Up" project. As a reminder, this national call for projects "Innovation territories" aims to develop some local demonstrators of innovation, which promote a more sustainable territorial development. They were one of the 24 French laureates. They received 7.5 million euros of subvention added to 15.5 million euros of their own funds (private and public) to create a "productive city" based on the concept of "Enterprises of Territory". These enterprises (and these entrepreneurs) must be different from the classic ones because their first aim is not to maximize profit, but to create positive externalities for the territory. They have to be ecologically responsible, socially involved, and locally anchoring to become the ambassadors for a new model of territorial development. The project is based on two axes, several tools and a new system of governance.

The first axis supports the development of some "Enterprises of Territory"that were chosen to be the ambassadors for building a new productive city. One of the emblems of this productive city is "The city of shoes" developed by the association of shoe manufacturers (Made in Romans), aided by a group of inhabitants. Located in the city center of Romans, this new manufacturing site is designed similar to a third place. It includes five production workshops visible to the public, a visitor center, a shop, and a restaurant. Other enterprises are selected because they have a positive social and ecological impact on the territory and they could be an example for the other entrepreneurs there and elsewhere. Several of them have been created by the "Territory Start-Up" process, imagined by citizens, or supported by them. A part of the subvention is used to accelerate their development and create a productive dynamic around them.

The second axis aims to support and accelerate the creation of new "Territory Start-Ups" through creative evenings. It is helped by the following three main devices to develop the productive eco-system:

1. An incubator (the fabT) based on local and collaborative mobilization would be located in a symbolic place (industrial third-place) to help new entrepreneurs;

2. A local financial tool based on financial cooperation between enterprises;

3. A Knowledge Brokerage Cooperative (CooCon), designed as a knowledge access platform. Inspired by a Quebec model, it provides small and medium-sized enterprises, start-ups, and more generally all citizens with easier access to training, research, university expertise, and partnership opportunities for entrepreneurial projects.

The system of project's governance associates "citizens-actors" with the decision-making process.

From our point of view, this socio-economic trajectory of Romans-sur-Isère reveals two mains levers for the medium-sized industrial towns' re-industrialization that we develop in the next section.

\section{Discussion: Cooperation and Social Innovation, Two Levers of Romans-sur-Isère Productive Rebirth}

For several authors, the cooperation between local stakeholders is the basis, or even the definition, of local development [69-71]. The socio-economic trajectory of Romans-sur-Isère should be an illustration of this process. More specifically, it is interesting to understand how this endogenous process based on local specificities was combined with exogenous opportunities (especially financial aids). In our opinion, this combination is one of the drivers of the rebirth of Romans-sur-Isère and, more generally, of territorial development. The second driver concerns innovation. Local development (from a productive 
point of view) is generally associated with technological innovation [72]. In Romans-sur-Isère, the social innovation seems more important to explain the productive rebirth than the technological one. These two levers could open new opportunities for medium-sized industrial towns.

\subsection{Local Stakeholders' Cooperation, Proximity, and Exogenous Levers}

The change from an economic activity marked by the footwear mono-industry, both in terms of number of jobs and image, to a diversified economic structure is the result of both endogenous and exogenous mechanisms. More precisely, it was not until the middle of the 2000s, i.e., the significant closures of the Charles Jourdan and Kélian companies, that local actors mobilized and worked collectively to diversify in line with the resources implemented by the State. Indeed, we said previously that among the actions put in place as part of the site contract, there was support for the partnership between leather-shoe industry companies and the creation of a platform for the reclassification of employees (conducted by the "House of employment" created). Through these two components, combined with exogenous development, it seems that this contract has supported the emergence of new institutional proximities based on collective action.

The TPEC has played a decisive role in promoting this revival of local industrial activity. It is thus at the origin of the Romans leather association in 2012. This association today gathers some 15 production workshops, both recent and older, mainly craftsmen. The aim is to strengthen the dynamics of cooperation between companies belonging to the leather and footwear sector in the living area. Then, in 2013, the association won the call for projects to support and promote French-made products launched by what was then the Ministry of Production Recovery, proposing to develop a program of action entitled "support the new economic model of Romans-sur-Isère shoemakers". Within the association, the members deal with various subjects ranging from work on purchasing to the setting up of common services and the creation of an inter-company crèche. They have also set up a common label called "Real shoe of Romans" (seven labelled brands that insist on the local production).

The shoe production that is being reborn in Romans-sur-Isère is based on rather classic and timeless collections, which require, more than luxury shoes, affordable prices. Cooperation is one of the bases of their competitiveness and territorial anchoring. Indeed, the TPEC as well as the Romans leather association promote direct exchanges of information as well as the sharing of the same codes, rules, and conventions. Cooperation also takes the form of concrete actions, supported by the two structures, deployed throughout the entire value chain of companies, both in production processes and distribution channels: Distribution of orders between each workshop according to their respective skills and workloads, collective participation in promotional fairs (e.g., Made in France Exhibition), etc.

In Romans-sur-Isère, it seems that the social economy stakeholders, the TPEC and the Romans leather association, and the initiative of the Archer group and its charismatic leader, Christophe Chevalier, have taken over, due to the inability of the public authorities to save the sector. Note that Archer was born in 1987 as a reaction to the deep crisis in the shoe industry. The integration enterprise seeks first to concentrate in a single organization a set of local energies to provide support to people suffering from long-term unemployment. Then, in the 2000s, as the reversible and transitory crisis took on a structural character, Archer reoriented its objectives and activities showing a growing interest in rescuing companies in difficulty. However, if the initiative seems to come from the private sector first, the cooperation between public and private actors has determined this. In 2016, the Archer social company once again launched the "Territory Start Up" initiative. However, the urban community of Valence-Romans-sur-Isère quickly joined the dynamic to respond, with success, to the national call for projects on "Innovation territories".

As we see, this last success is the result of a long process of cooperation between private and public stakeholders from the local area, supported by national or international level. One aspect of this cooperation between public and private stakeholders is that it is based on personal interrelations. Behind the term of "local stakeholders", there are people who have worked and lived in the same place for several decades. Therefore, their proximity is very important. The concept of proximity, developed by 
several researchers in regional science [71,73-76], considers two mains proximities (one geographic and one organizational). The different analysis grids proposed by previous authors [77-80] are not yet fixed, but in most of these works, space is not absent; however, it is not considered as a necessary condition for other forms of proximity. It is assigned a secondary place while the focus is on the deepening of organizational proximities (i.e., perceived as an analysis of human relations to those described by standard economic theory) [81]. Organizational proximities (i.e., direct exchanges of information or various flows made possible by membership of the same organization) within TPEC and the Romans Leather Association, and institutional proximities (i.e., sharing of codes, rules of conventions) throughout historical collective action are relevant for the renewal observed in Romans-sur-Isère. Nevertheless, our study leads us to believe that the size of the city, in the sense "geographical proximity", influences the two other forms of proximity. In the case of Romans-sur-Isère, the professional and personal interrelation between entrepreneurs, researchers, inhabitants, decision-makers, and elected officials have created a favorable basis to re-think a new productive path, based on values, social, and environmental impacts more than profit and capitalization.

This project emphasizes the role of social innovation to imagine and to build a new "productive city" in a medium-sized town.

\subsection{Social Innovation, as Productive Development Driver}

We know the importance, for small and medium-sized towns, of the embedding of economic activities in social structures [5,20]. Our purpose is now to consider the social innovation (based on the social structures) as a driver to renew the productive economy. We use the definition given by the Center for Research on Social Innovations-CRISES (UQAM, Canada), as follows: "an intervention initiated by social actors to respond to an aspiration, meet a need, provide a solution or take advantage of an opportunity for action in order to modify social relations, transform a framework for action or propose new cultural orientations". The local level constitutes a privileged place for the emergence of these social innovations, which are recognized as context specific [82,83].

Among the five types of social innovation's type identified by TEPSIE [84], the last local initiative that has emerged in Romans-sur-Isère called "Capital of the territory start-ups" relies on four of them.

The first one is a new process with the mobilization of all the stakeholders in the area, including the inhabitants, in a broadly inclusive manner. While citizen participation is not a new phenomenon in urban or regional planning in industrial areas (e.g., International Building Exhibition (IBA) Emscher Park in Germany [85] or more recently in the case of Nord-Pas-de-Calais mining basin in France, both converted in heritage sites [86]), it is much rarer for entrepreneurial issues. The challenge launched during creative evenings is to think locally and collectively about the responses that could be made to the social needs experienced locally to move towards a new development model. They try to imagine, develop, support, and build business projects and start-ups that offer the services that the region needs. This project aims to be an incubator and catalyst of new ideas likely to contribute to the economic and potentially productive renewal of the local fabric and to create jobs.

The second one is a new organizational form. Indeed, the governance includes two existing piloting committees, that of "Territory Start-Up" (based on private stakeholders and citizens) and that of the economic development to the local inter-municipalities (i.e., 23 actors from socio-economic private and public sectors and citizens). This new form of governance should also manage both "French Tech" and "French Impact" labels. In 2019, the territory obtained the French Impact label. According to local stakeholders, the case of Romans-sur-Isère would even have inspired the French state in the creation of this label. This label reveals new trends in the social economy. Its name is intended to echo the French Tech movement and aims to federate the ecosystem of social and environmental economy, that place the social innovation as a lever of development.

The third one, new practices, encompasses the evaluation of the project. The choice has been made to mobilize academic researchers and experts to evaluate "in itinere" the process, based on classic variables (i.e., employment, income, added value), but also based on a collaborative process that 
includes a citizen impact assessment. An international committee for evaluating was also formed, i.e., Marcos Garcia (Director of Media Lab Prado, Madrid), Minh Man Nguyen (President of the Fab City Grand Paris), and Andrés Borthagaray (Director of planning in Buenos Aires) agreed to participate.

The fourth one corresponds to new services and products collectively imagined to respond to local needs. The objective is to create around 100 companies and 1500 direct jobs. Considering market-based solutions as social innovation could be discussed. However, according us, it is relevant because it is the result of the three other types of social innovation. The construction of this initiative is very particular: The local entrepreneurs are mobilized and are at the same time the initiators and maneuvers. While relying on their corporate culture, their social and territorial responsibility is apparent. In line with the TPEC, this approach re-examines the role of local authorities in driving economic development. It also shows that attractiveness is not the only source of redevelopment: It is possible to build on local ideas and needs, including in a medium-sized industrial town and regarding productive means. Although medium-sized industrial towns are not the best endowed in terms of knowledge, skilled labor or capital dynamics can nevertheless mobilize their combinatorial capacity to capture resources outside the territory.

Of course, we have to nuance to qualify our statements. There is not enough precedent for us to know the results of this ambitious project. For the moment, for example, it is hard to know the quantitative results. For example, in 2014, based on the scale of the living area, the footwear sector employed only 170 people $(0.9 \%$ of local employment, i.e., $0.04 \%$ in France) and 140 people in Romans-sur-Isère (data from Accoss (Central Agency for Social Security Bodies)). However, qualitatively, the process is a tangible result from a point of view of cooperation and collective imagination of a future without excluding a productive way.

\section{Conclusions: The Medium-Sized, A New Asset?}

For several decades, medium-sized industrial towns have been socio-economically weakened because of a combination of economic and political processes as globalization, deindustrialization, metropolization, and withdrawal of public services. In the meantime, urban, regional, and industrial policies have focused more and more on metropolises seen as the core of economic and productive growth of nations. However, in France, we recently observed a renewed attention for these towns, especially for territorial cohesion reasons and not because a national economic issue. While they are often seen as shrinking or requiring measures for cultural or residential redevelopment, this article has looked at potential roots and levers of a productive renewal for medium-sized industrial towns.

Since 1975, in France, our study shows a great diversity of situation for medium-sized industrial towns, like in other European countries [8]. Only a few of them have managed to renew their productive base [9]. Some of them, in shrinkage, have decreased in terms of jobs and/or population over the period underlying probable major socio-economic difficulties. Others, in what we called mutation path, have turned to residential pillars of development. This is the case of Romans-sur-Isère, our case study. While the dominant paradigm of factor mobility and agglomeration economies is satisfactory in explaining metropolitan dynamics, this is less the case for medium-sized industrial towns. Thus, how could explain the new productive dynamics and entrepreneurial mobilization in this ex-capital of shoe industry, be explained?

Since the big local crisis of the mid-2000s, our surveys and our participant observation show the different organizations created, processes initiated, and national funds captured. By highlighting their origins and particularities, we argue that social innovation (more than technologic innovation) and the cooperation between the stakeholders explain most of this attempt of productive renewal. The revival does not stand out from the city's industrial history. In contrast, it is inspired by it. Regarding the importance of social innovation for challenging issues in medium-sized industrial towns, we join the results of Gordon [83] (i.e., a wide range of creative answers, connections with elsewhere, individual efforts supported by local authorities), but the case of Romans-sur-Isère stands out because of the role played by local businesses and their cooperation. We show that the productive innovation resources of 
medium-sized industrial towns could lie in their capacity to be territories of experimentation of social innovation. Furthermore, this renewal cannot be considered as a simple endogenous model based on a local industrial system. In the case of Romans-sur-Isère, the links with the outside through private partnership, public funding, or national and international networks have always been determining factors to reorganize the local production. The private and public stakeholders seem to know how to maximize this combination between endogenous and exogenous drivers that characterize, in our network society, the territorial development.

The case of Romans-sur-Isère is not exactly replicable, but it could inspire other towns and local stakeholders to combine regional policies to local specificities towards a productive future. Each town must do with its own characteristics and strengths and each one can draw on its industrial history and local needs to imagine its own productive future. To make it possible, there is a need of urban and regional policies, not just growth-oriented, that could take into account local specificities (like Innovation territories). If the participation of inhabitants is something new for determining business issues, cooperation between public and private stakeholders observed in Romans-sur-Isère and, of course, local specificities result from a construction over a long time, at times encouraged by public policies.

Finally, we would like to open discussion about the role of space or geography. In a context of ecological transition, the medium-sized city could be a real advantage for European towns. It may no longer be so much the size of the market and the degree of export that will determine the new economic development, as was the case since 1990s in metropolitan areas, but the social compacity of the system. Indeed, behind what we called "public" and "private" stakeholders, there are people who work and live in the same place for a long time. This personal and spatial proximity seems to help local coordination, social innovation, and, finally, citizen empowerment. Medium-sized towns could be a new experimental place to rethink our economic model. New future research and new international comparison could be interesting to study the productive capacity of these towns based on socially and territorially anchored bottom-up initiatives regarding the need of resilience.

Author Contributions: Conceptualization, M.T. and M.G.-B.; methodology, M.G.-B. and M.T.; writing-original draft preparation, M.G.-B. and M.T.; writing-review and editing, M.G.-B. and M.T.; visualization, M.G.-B. All authors have read and agreed to the published version of the manuscript.

Funding: This research was funded by the Rhône-Alpes Region and via the "Innovation Territories" project (State Investment Program for the Future).

Conflicts of Interest: The authors declare no conflict of interest.

\section{References}

1. Delpirou, A. La Couleur Des Gilets Jaunes. Vie Idées; Collège de France: Paris, France, 2018.

2. Depraz, S. La France contrainte des gilets jaunes. Anal. Opin. Crit 2019, 1, 75-80.

3. Paddison, R.; Rae, N. Brexit and Scotland: Towards a political geography perspective. Soc. Space 2017, 13, $1-18$.

4. Monnat, S.M.; Brown, D.L. More than a rural revolt: Landscapes of despair and the 2016 Presidential election. J. Rural Stud. 2017, 55, 227. [CrossRef] [PubMed]

5. Carrier, M.; Demazière, C. Introduction La socio-économie des villes petites et moyennes. Questions théoriques et implications pour l'aménagement du territoire. Rev. Deconomie Reg. Urbaine 2012, 2, 135-149. [CrossRef]

6. Navereau, B.; Tallec, J.; Zuliani, J.-M. Les logiques territoriales des «mondes de production» de petites villes. Vers une lecture renouvelée des centralités? Belg 2019. [CrossRef]

7. Authier, J.-Y.; Bidou-Zachariasen, C. Éditorial. Ces villes dont on ne parle pas. Espac. Soc. 2017, 168, 9-16. [CrossRef]

8. Bright Future for Black Towns-Economic Performance and Place-Based Characteristics of Industrial Regions in Europe. 2017. Available online: https://www.researchgate.net/publication/325195233_Economic_ performance_and_placebased_characteristics_of_industrial_regions_in_Europe (accessed on 2 April 2020). 
9. Demazière, C. Le traitement des petites et moyennes villes par les études urbaines. Espac. Soc. 2017, 168, 17-32. [CrossRef]

10. Wolff, M.; Fol, S.; Roth, H.; Cunningham-Sabot, E. Shrinking Cities, villes en décroissance: Une mesure du phénomène en France. Cybergeo: Eur. J. Geogr. 2013. [CrossRef]

11. Taulelle, F. La France des villes petites et moyennes. In La France: Une géographie urbaine; Cailly, L., Vanier, M., Eds.; Armand Colin: Paris, France, 2010; pp. 149-168.

12. Desjardins, X.; Estèbe, P. Villes Petites et Moyennes et Aménagement Territorial—Eclairages Anglais, Allemands et Italiens sur le cas Français; PUCA: Paris, France, 2019.

13. Santamaria, F. Les villes moyennes françaises et leur rôle en matière d'aménagement du territoire: Vers de nouvelles perspectives? Norois 2012, 1012, 13-30. [CrossRef]

14. Berroir, S.; Fol, S.; Quéva, C.; Santamaria, F. Villes moyennes et dévitalisation des centres: Les politiques publiques face aux enjeux d'égalité territoriale. Belg 2019. [CrossRef]

15. Thisse, J.-F.; Van Ypersele, T. Métropoles et concurrence territoriale. Econ. Stat. 1999, 326, 19-30. [CrossRef]

16. Pribetich, J. Explorer la ville moyenne à Auxerre et à Vienne. Retour sur deux études fondatrices de la sociologie urbaine française. Espac. Soc. 2017, 168, 33-50. [CrossRef]

17. Martin, R.; Sunley, P.; Tyler, P.; Gardiner, B. Divergent cities in post-industrial Britain. Camb. J. Reg. Econ. Soc. 2016, 9, 269-299. [CrossRef]

18. Hobor, G. Surviving the Era of Deindustrialization the New Economic Geography of the Urban Rust Belt. J. Urban Aff. 2013, 35, 417-434. [CrossRef]

19. Moretti, E. The New Geography of Jobs; Houghton Mifflin Harcourt: Boston, MA, USA, 2012.

20. Hamdouch, A.; Demaziere, C.; Banovac, K. The Socio-Economic Profiles of Small and Medium-Sized Towns Insights from European Case Studies. Tijdschr. Voor Econ. En Soc. Geogr. 2017, 108, 456-471. [CrossRef]

21. Rodríguez-Pose, A. The revenge of the places that don't matter and what to do about it. Camb. J. Reg. Econ. Soc. 2018, 11, 189-209. [CrossRef]

22. Estèbe, P. Petites villes et villes moyennes: Une leçon de choses. Tous Urbains 2018, 21, 30-35. [CrossRef]

23. Shrinking Cities: International Perspectives and Policy Implications; Pallagst, K.; Wiechmann, T.; Martinez-Fernandez, C. (Eds.) Routledge: New York, NY, USA; Abingdon, UK, 2013.

24. Bontje, M. Facing the challenge of shrinking cities in East Germany: The case of Leipzig. GeoJournal 2004, 61, 13-21. [CrossRef]

25. Martinez-Fernandez, C.; Audirac, I.; Fol, S.; Cunningham-Sabot, E. Shrinking cities: Urban challenges of globalization. Int. J. Urban Reg. Res. 2012, 36, 213-225. [CrossRef]

26. Hollander, J.-B.; Pallagst, K.; Schwarz, T.; Popper, F.-J. Planning shrinking cities. Prog. Plan. 2009, 72, $223-232$.

27. Schilling, J.; Logan, J. Greening the rust belt: A green infrastructure model for right sizing America's shrinking cities. J. Am. Plan. Assoc. 2008, 74, 451-466. [CrossRef]

28. Shetty, S.; Reid, N. Dealing with Decline in Old Industrial Cities in Europe and the United States: Problems and Policies. Built Environ. 2012, 40, 458-474. [CrossRef]

29. Béal, V.; Fol, S.; Miot, Y.; Rousseau, M. Varieties of right-sizing strategies: Comparing degrowth coalitions in French shrinking cities. Urban Geogr. 2017, 40, 1-23.

30. Florida, R.L. The Rise of the Creative Class and How it's Transforming Work, Leisure, Community and Everyday Life; Basic Books: New York, NY, USA, 2002.

31. Gabe, T.M.; Abel, J.R. Shared Knowledge and the Co-agglomeration of Occupations. Reg. Stud. 2016, 50, 1360-1373. [CrossRef]

32. Scott, A.J. Resurgent Metropolis Economy, Society and Urbanization in an Interconnected World. Int. J. Urban Reg. Res. 2008, 32, 548-564. [CrossRef]

33. Glaeser, E. Triumph of the City How Our Greatest Invention Makes Us Richer, Smarter, Greener, Healthier, and Happier; Penguin: London, UK, 2011.

34. Combes, P.-P.; Duranton, G.; Gobillon, L.; Puga, D.; Roux, S. The productivity advantages of large cities distinguishing agglomeration from firm selection. Econometrica 2012, 80, 2543-2594.

35. Krugman, P.R. Geography and Trade; MIT Press: Cambridge, MA, USA, 1991.

36. Combes, P.-P.; Gobillon, L. The Empirics of Agglomeration Economies. In Handbook of Regional and Urban Economics; Duranton, G., Henderson, J.V., Strange, W.C., Eds.; Elsevier: Amsterdam, The Netherlands, 2015; pp. 247-348. 
37. Combes, P.-P.; Duranton, G.; Gobillon, L. The identification of agglomeration economies. J. Econ. Geogr. 2011, 11, 253-266. [CrossRef]

38. Carlino, G.; Kerr, W.R. Agglomeration and Innovation. In Handbook of Regional and Urban Economics; Duranton, G., Henderson, J.V., Strange, W.C., Eds.; Elsevier: Amsterdam, The Netherlands, 2015; pp. 349-404.

39. Giannakis, E.; Bruggeman, A. Determinants of regional resilience to economic crisis: A European perspective. Eur. Plan. Stud. 2017, 25, 1394-1415. [CrossRef]

40. McCann, P.; Ortega-Argilés, R. Smart specialization, regional growth and applications to European Union cohesion policy. Reg. Stud. 2015, 49, 1291-1302. [CrossRef]

41. Ramajo, J.; Marquez, M.A.; Hewings, G.J.; Salinas, M.-M. Spatial heterogeneity and interregional spillovers in the European Union: Do cohesion policies encourage convergence across regions? Eur. Econ. Rev. 2008, 52, 551-567. [CrossRef]

42. Dormois, R.; Fol, S. Urban Shrinkage in France: An Invisible Issue? 2017. Available online: https: //www.metropolitiques.eu/IMG/pdf/met-dormois-fol-eng.pdf (accessed on 2 April 2020).

43. Kahn, R. Le tournant métropolitain de la politique régionale européenne-L'observatoire des politiques économiques en Europe. Bull. Obs. Polit. Économiques En Eur. 2017, 36, 43-48.

44. Tewdwr-Jones, M.; Mourato, J.-M. Territorial cohesion, economic growth and the desire for European' balanced competitiveness'. Town Plan. Rev. 2005, 76, 69-80. [CrossRef]

45. European Commission. Green Paper on Territorial Cohesion: Turning Territorial Diversity into Strength. Communication from the Commission to the Council, the European Parliament, the Committee of the Regions and the European Economic and Social Committee. 2008. Available online: https://www.google.com/url?sa=t\&rct=j\&q=\&esrc=s\&source=web\&cd=1\&ved= 2ahUKEwihqY6696HoAhUIyKYKHQnUAP0QFjAAegQIBBAB\&url=https\%3A\%2F\%2Feur-lex.europa. eu\%2FLexUriServ\%2FLexUriServ.do\%3Furi\%3DCOM\%3A2008\%3A0616\%3AFIN\%3AEN\%3APDF\&usg= AOvVaw12qeUupb_4W7NuaMeHOGrv (accessed on 20 January 2020).

46. Cassaigne, B. Villes moyennes. Rev. Proj. 2009, 313, 78-83. [CrossRef]

47. Delpirou, A. Villes Moyennes. 2013. Available online: https://www.metropolitiques.eu/Villes-moyennes-595. html (accessed on 2 April 2020).

48. Talandier, M. Les Villes Moyennes, des Espaces Privilégiés de la Consommation Locale. 2014. Available online: https://www.aradel.asso.fr/upload/File/bibliotheque/villes $\% 20$ moyennes $\%$ 20consommation\%20locale_937022.pdf (accessed on 2 April 2020).

49. Nadou, F. La notion de 'villes intermédiaires', une approche différenciée du rôle des villes moyennes entre structuration territoriale et spécificités socio-économiques. In Proceedings of the Villes Petites et Moyennes, un Regard Renouvelé, Tours, France, 9-10 December 2012.

50. De Roo, P. Des charnières territoriales à conforter. Rev. Urban. 2011, 378, 5-9.

51. Baudelle, G.; Tallec, J. Les villes moyennes sont-elles les perdantes de la mondialisation? Pouvoirs Locaux Cah. Décent. Inst. Décent. 2008, 77, 89-94.

52. Strategic Guide for Developing Urban Policies in Industrial Towns; Cercleux, A.-L.; Bole, D. (Eds.) University Press: Bucharest, Romania, 2019.

53. French Government. Territoires D'innovation. 24 Projets Lauréats. Press Kit; French Government: Paris, France, 2019.

54. Sieber, S.D. The Integration of Fieldwork and Survey Methods. Am. J. Sociol. 1973, 78, 1335-1359. [CrossRef]

55. Johnson, R.B.; Onwuegbuzie, A.J. Mixed Methods Research A Research Paradigm Whose Time Has Come. Educ. Res. 2004, 33, 14-26. [CrossRef]

56. Tashakkori, A.; Creswell, J.W. The New Era of Mixed Methods; Sage Publications: New York, NY, USA, 2007.

57. Creswell, J.-W.; Plano Clark, V.L. Designing and Conducting Mixed Methods Research; Sage: Thousand Oaks, CA, USA, 2007.

58. Methods That Matter. Integrating Mixed Methods for More Effective Social Science Research; Hay, M.C., Ed.; University of Chicago Press: Chicago, IL, USA, 2016.

59. Clark, C. The Conditions of Economic Progress; Macmillan: London, UK, 1947.

60. Martin, R.; Sunley, P.; Gardiner, B.; Tyler, P. How Regions React to Recessions Resilience and the Role of Economic Structure. Reg. Stud. 2016, 50, 561-585. [CrossRef]

61. Bouba-Olga, O. Eloge de la Diversité; Atlantique: Poitiers, France, 2017. 
62. Carré, D.; Levratto, N. Les Performances des Territoires. Les Politiques Locales, Remèdes au déclin Industriel; Editions Le Manuscrit: Paris, France, 2011.

63. Carré, D.; Levratto, N. Les Entreprises du Secteur Compétitif dans Les Territoires. Les Déterminants de la Croissance; Rapport Pour l'Assemblée des Communautés de France: Paris, France, 2013.

64. Carré, D.; Levratto, N.; Frocrain, J.-P. L'étonnante Disparité des Territoires Industriels. Comprendre la Performance et le Déclin; Presses des Mines: Paris, France, 2019.

65. Martin, R.; Sunley, P. On the notion of regional economic resilience conceptualization and explanation. J. Econ. Geogr. 2015, 15, 1-42. [CrossRef]

66. Bouchardeau, P. L'économie romanaise: Reprise, diversification et difficile reconversion (1960-2016). In Histoire de Romans-sur-Isère; Pau, A., Ed.; Privat: Toulouse, France, 2016; pp. 409-422.

67. Le Bot, F.; Perrin, C. Mobiliser l'industrie de la chaussure, mobiliser ses territoires. Terrains Trav. 2011, 2, 205-224. [CrossRef]

68. Perret, C. Du District Industriel au Pôle Territorial de Coopération Économique. La Chaussure de Romans-sur-Isère vers un Renouveau Productif? Notes Rech. Irege; HAL: Bengaluru, India, 2015.

69. Pecqueur, B. Le Développement Local; La Découverte: Paris, France, 1989.

70. Courlet, C.; Pecqueur, B. L'économie Territoriale; PUG: Grenoble, France, 2013.

71. Torre, A. Territorial development and proximity relationships. In Handbook of Regional and Development Theories, 2nd ed.; Capello, R., Nijkamp, P., Eds.; Edward Elgar Publishing: Cheltenham, UK, 2019; pp. 326-343.

72. Moulaert, F.; Sekia, F. Territorial Innovation Models A Critical Survey. Reg. Stud. 2003, 37, 289-302. [CrossRef]

73. Gilly, J.-P.; Torre, A. Dynamiques de Proximité; L'Harmattan: Paris, France, 2000.

74. Bouba-Olga, O.; Grossetti, M. Socio-économie de proximité. In Revue D'économie Régionale Urbaine; Université de Poitiers: Grand-Poitiers, France, 2010; pp. 311-328.

75. Boschma, R. Proximity and Innovation A Critical Assessment. Reg. Stud. 2005, 39, 61-74. [CrossRef]

76. Knoben, J.; Oerlemans, L.G. Proximity and inter-organizational collaboration: A literature review. Intern. J. Manag. Rev. 2006, 8, 71-89. [CrossRef]

77. Bouba-Olga, O.; Coris, M.; Carrincazeaux, C. Avant-propos. In Revue Déconomie Régionale Urbaine; Université de Poitiers: Grand-Poitiers, France, 2008; pp. 279-287.

78. Torre, A.; Rallet, A. Proximity and Localization. Reg. Stud. 2005, 39, 47-59. [CrossRef]

79. Pecqueur, B.; Zimmermann, J.-B. Économie de Proximités; Hermès Science Publications: Paris, France, 2004.

80. Talbot, D. Les institutions créatrices de proximités. In Revue D'économie Régionale Urbaine; Université de Poitiers: Grand-Poitiers, France, 2008; pp. 289-310.

81. Torre, A. Retour sur la notion de Proximité Géographique. Geogr. Econ. Soc. 2009, 11, 63-75. [CrossRef]

82. Klein, J.-L.; Laville, J.-L.; Moulaert, F. L'innovation Sociale; Editions Erès: Toulouse, France, 2014.

83. Gordon dir., C. Identifying Social Innovations in Industrial Towns a Comparative Perspective in Bright Future. 2019. Available online: https://jpi-urbaneurope.eu/app/uploads/2019/10/Bright-Future-Synthesis-report.pdf (accessed on 2 April 2020).

84. TEPSIE. Social Innovation Theory and Research: A Summary of the Findings. 2014; Available online: https:/iupe.files.wordpress.com/2015/11/tepsie-research_report_final_web.pdf (accessed on 2 April 2020).

85. Shaw, R. The International Building Exhibition (IBA) Emscher Park, Germany: A Model for Sustainable Restructuring? Eur. Plan. Stud. 2002, 10, 77-97. [CrossRef]

86. Talandier, M.; Navarre, F.; Cormier, L.; Landel, P.A.; Ruault, J.F.; Senil, N. Outstanding Heritage Sites-A Resource for Territories; Editions PUCA: Paris, France, 2019.

(C) 2020 by the authors. Licensee MDPI, Basel, Switzerland. This article is an open access article distributed under the terms and conditions of the Creative Commons Attribution (CC BY) license (http://creativecommons.org/licenses/by/4.0/). 